\title{
A EXPERIENCIA DE APRENDIZAGEM DE ALUNOS DE ENFERMAGEM NA INTERAÇÃO COM PACIENTES
}

\author{
Margareth Angelo *
}

\section{NOTA PRÉVIA}

ANGELO, $M$. A experiência de aprendizagem de alunos de enfermagem na interação com pacientes. Nota prévia. Rev. Esc. Enf. USP, São Paulo, 20(3):271, 1986.

A autora pretende obter elementos que lhe permitam compreender a experiência de aprendizagam de alunos de enfermagem, em relação à interação com pacientes.

Devido à natureza pessoal e subjetiva das informações pretendidas, a autora optou por desenvolver o trabalho segundo metodologia qualitativa.

A abordagem qualitativa empregada neste estudo é a metodologia para descoberta de teoria fundamentada em dados, proposta por GLASER \& STRAUSS.

O estudo encontra-se em fase de coleta de dados.

\section{NURSING STUDENTS' LEARNING EXXPERIENCE OF INTERACTION WITH PATIENTS}

ANGELO, M. Nursing students learning experience of interaction with patients. Preliminary note. Rev. Esc. Enf. USP, São Paulo, 20(3):271, 1986.

The author intends to obtain elements to understand the nursing students learning experience of interaction with patients.

Because of the personal and subjective nature of the intended data, this study will be developed according to the qualitative methodology.

The adapted qualitative methodology is the Grounded Theory approach proposed by GLASER \& STRAUSS.

This study is in the data collection phase.

\section{REFERENCIA BIBLIOGRÁFICA}

GLASER, B.G. \& STRAUSS, A.L. The discovery of grounded theory. New York, Aldine, 1967. 271 p.

\footnotetext{
* Enfermeira. Mestre em Enfermagem. Professor Assistente do Departamento de Enfermagem Materno-Infantil e Psiquiatrica da Escola de Enfermagem da USP - disclplina Enfermagem Pediatrica.
} 